Animal Reproduction

Received on: 02/11/2020

Accepted on: 05/05/2021

\title{
Antifungal and antioxidant effect of the lachnophyllum ester, isolated from the essential oil of Baccharis trinervis (Lam.) Pers., against dermatophytes fungi
}

\author{
Efeito antifúngico e antioxidante do éster lacnofilum, isolado do óleo essencial de \\ Baccharis trinervis (Lam.) Pers., contra fungos dermatófitos
}

\author{
${ }^{1 *}$ SOBRINHO, Antônio Carlos Nogueira \\ http://orcid.org/0000-0002-9921-3350
}

${ }^{2}$ FONTENELLE, Raquel Oliveira dos Santos https://orcid.org/0000-0003-1133-6231

\author{
${ }^{2}$ SOUZA, Elnatan Bezerra de \\ https://orcid.org/0000-0002-5222-4378 \\ ${ }^{3}$ MORAIS, Selene Maia de \\ https://orcid.org/0000-0002-2766-3790
}

\footnotetext{
${ }^{1}$ Universidade Estadual do Ceará-UECE, Faculdade De Educação, Ciências e Letras de Iguatu, av. Dr. Dario rabelo s/n, bairro Santo Antônio, CEP: 63.502-253, Iguatu/CE, Brasil

${ }^{2}$ Universidade Estadual Vale do Acaraú - UVA - Av. da Universidade, 850 - Campus da Betânia - Sobral-CE, CEP: 62.040-370, Brasil

${ }^{3}$ Universidade Estadual Do Ceará - UECE, Av. Dr. Silas Munguba, 1700 - Campus Do Itaperi Fortaleza, CE, CEP: 60.714.903 Brasil
}

*Mail for correspondence: caiosobrinho@yahoo.com.br

\begin{abstract}
Dermatophytes are hyaline fungi that parasitize the keratinized tissue of humans and animals causing mycotic infections. Natural products are promising molecules for the development of new antifungal drugs, due to the phenomenon of resistance and toxicity. This study reports the isolation and identification of lachnophyllum ester and evaluates its antioxidant, antifungal and modulatory activities against dermatophytes fungi. Lachnophyllum ester was obtained using a silica gel column chromatography of the essential oil from the aerial parts of Baccharis trinervis and analyzed by gas chromatography/mass spectrometry. Antimicrobial activity was determined by the broth microdilution method. The modulatory activity assays were performed by the checkerboard technique using lachnophyllum ester and ketoconazole as standard. The lachnophyllum ester exhibited good antioxidant activity as measured by a $\beta$ carotene/linoleic acid bleaching system, with $71.43 \% \pm 0.01 \%$ inhibition rate. In addition, it showed antifungal activity against Trichophyton rubrum and Microsporum canis strains. In the modulatory assay, interaction between lachnophyllum ester and ketoconazole was synergistic, reducing the minimum inhibitory concentration (MIC) values of the antifungal drug and modulating its antifungal action against dermatophyte strains. In conclusion, lachnophyllum ester has been shown to act as a natural antioxidant compound, as well as an antimicrobial alternative against dermatophyte fungi of the genus Trichophyton and Microsporum.
\end{abstract}


Keywords: ketoconazole; ester-type polyacetylenes; antidermatophytic activity; keratinophilic fungi.

\section{RESUMO}

Dermatófitos são fungos hialinos que parasitam o tecido queratinizado de humanos e animais causando infecções fúngicas. Os produtos naturais são moléculas promissoras para o desenvolvimento de novos fármacos antifúngicos, devido ao fenômeno de resistência e a toxicidade. Este estudo relata o isolamento e a identificação do éster lacnofilum e avalia sua atividade antioxidante, antifúngica e modulatória contra fungos dermatófitos. O éster lacnofilum foi obtido por cromatografia em coluna de sílica gel do óleo essencial das partes aéreas da Baccharis trinervis e analisado por cromatografia gasosa/espectrometria de massa. A atividade antimicrobiana foi determinada pelo método de microdiluição em caldo. Os ensaios de atividade modulatória foram realizados pela técnica de checkerboard, utilizando éster lacnofilum e cetoconazol como padrão. O éster lacnofilum exibiu boa atividade antioxidante, medida pelo sistema $\beta$-caroteno/ácido linoléico, com taxa de inibição de $71,43 \% \pm 0,01 \%$. Além disso, mostrou atividade antifúngica contra as cepas de Trichophyton rubrum e Microsporum canis. No ensaio modulatório, a interação entre éster lacnofilum e cetoconazol foi sinérgica, reduzindo os valores concentração inibitória mínima (CIM) do antifúngico e modulando sua ação antifúngica contra cepas de dermatófitos. Em conclusão, o éster lacnofilum demonstrou atuar como um composto antioxidante natural, bem como uma alternativa antimicrobiana contra fungos dermatófitos do gênero Trichophyton e Microsporum.

Palavras-chave: cetoconazol; éster do tipo poliacetileno; atividade antidermatófítica; fungos queratinófilos.

\section{INTRODUCTION}

Natural products derived from medicinal plants are of great interest in medicine, in the food industry and, more recently, in biotechnology, through prospecting studies with the purpose of identifying bioactive molecules (Harvey, EdradaEbel and Quinn, 2015). Essential oils are natural products with significant biological and medicinal potential, due to their chemical composition rich in terpenoids and phenylpropanoids (Nazzaro et al., 2017).

Various herbal medicines rich in essential oils exhibit antifungal action without side effects to human and animal health. This factor is important because many of the current antifungal drugs can cause adverse effects in patients, besides leading to selection for resistance through the adaptation of antifungalresistant microorganisms (Tabassum and Vidyasagar, 2013). Dermatophyte fungi, such as those of the genera Trichophyton and Microsporum, which mainly affect the skin, hair, and nails (Bouchara, Mignon and Chaturvedi, 2017), cause the most prevalent mycoses worldwide. However, natural products with antioxidant and antimicrobial properties that can stabilize free radical molecules show promise for the development of new phytotherapeutic drugs (Jummes et al., 2020). 
Baccharis trinervis (Lam.) Pers. is a medicinal plant with wide use in Latin American folk medicine as a digestive aid, antiseptic and in the treatment of snakebites, general diarrhea, and hemorrhoids (Berlin and Berlin, 2015; Ramírez-Cárdenas et al., 2013). It is a perennial rhizomatous shrub with few branches, reaching a height between 80 $140 \mathrm{~cm}$ (Albuquerque et al., 2004). It occurs in the Americas from Argentina to Mexico. In Brazil, it is popularly known as "assapeixe-branco" or "assapeixe-fino".

Phytochemical studies have identified several secondary metabolite classes, such as neoclerodane-type diterpenes (Kuroyanagi et al., (1993), flavones (Sharp et al., 2001) and polyacetylenes (Bohlmann, 1988). Essential oil analysis has shown the presence of mainly monoterpenes, with sabinene and $\beta$ phellandrene being the major constituents, in addition to the presence of (Z)-lachnophyllum and (E)lachnophyllum esters (Sobrinho et al., 2016; Albuquerque et al., 2004).

The aim of this work was to isolate and identify the lachnophyllum ester from Baccharis trinervis and characterize its medicinal properties, including antifungal, antioxidant, and modulatory activities.

\section{MATERIALS AND METHODS}

All chemicals and reagents, if not stated otherwise, were obtained from SigmaAldrich Co (St. Louis, MO, USA), at the highest available grades.

Flowering aerial parts of $B$. trinervis were collected in the Meruoca Mountain region, $210 \mathrm{Km}$ west of Fortaleza, Brazil, in a semideciduous forest environment located around $800 \mathrm{~m}$ above sea level (latitude $3^{\circ} 3^{\prime} 3^{\prime \prime} \mathrm{S}$, longitude 40 40' 40" W), in June 2015. A voucher specimen (no. 3651) authenticated by botanist Dr. Elnatan Bezerra de Souza, have been deposited in the Francisco José de Abreu Matos Herbarium (HUVA) of the State University of Vale do Acaraú, Brazil.

Fresh aerial parts of $B$. trinervis $(300 \mathrm{~g}$ ) were subjected to hydrodistillation for 4 $h$ in a modified Clevenger-type apparatus. The oil was dried over anhydrous $\mathrm{Na}_{2} \mathrm{SO}_{4}(\sim 1 \mathrm{~g})$, filtered and preserved in a sealed vial at $4{ }^{\circ} \mathrm{C}$ prior to further analysis, with a yield of $0.2 \%$ (w/w). An aliquot of $500 \mathrm{mg}$ of essential oil was subjected to silica gel 60 (Merck, 230-240 mesh) column chromatography eluted with a gradient initially of hexane, followed by elution with mixtures of hexane, ethyl acetate and methanol in proportions with increasing polarity. Thirty-one fractions $(10 \mathrm{~mL})$ were collected, monitored by thin-layer chromatography (TLC), and the following fractions were pooled: 2-5 (A); 6-10 (B); 11-16 (C); 27-31 (D), to yield three major fractions. Fraction A, composed of the lachnophyllum ester, was analyzed by gas chromatography/mass spectrometry (GC/MS).

The B. trinervis essential oil was analyzed by Shimadzu QP-2010 Ultra instrument employing the following conditions: Rtx-5MS column (crossbond $5 \%$, diphenyl/95\% dimethyl polysiloxane) with $30 \mathrm{~m} \times 0.25 \mathrm{~mm} \times$ $0.25 \mu \mathrm{m}$ df; He carrier gas (24.2 $\mathrm{mL} / \mathrm{min}$ ), in constant linear velocity mode); injector temperature of $250{ }^{\circ} \mathrm{C}$, in split mode (1:100), and detector temperature of $250{ }^{\circ} \mathrm{C}$. The column temperature was programmed from 35 to $180^{\circ} \mathrm{C}$ at $4^{\circ} \mathrm{C} / \mathrm{min}$ and then 180 to 280 ${ }^{\circ} \mathrm{C}$ at $17^{\circ} \mathrm{C} / \mathrm{min}$, and finalized at $280^{\circ} \mathrm{C}$ 
for $10 \mathrm{~min}$. The mass spectra were obtained at an electron impact of $70 \mathrm{eV}$. $1 \mu \mathrm{L}$ of essential oil was injected. The components were identified from their GC retention times, calculated by linear interpolation relative to retention times of main compounds and by comparison of their temperature-programmed retention indices and mass spectra with those present in the commercial libraries (NIST) and published literature, through with those described by Adams (Adams, 2017).

The assay was determined by the broth microdilution test, carried in 96-well plates, in accordance with the M38-A guidelines of the Clinical and Laboratory Standards Institute (CLSI, 2008). Trichophyton rubrum was obtained from the fungal collection of the Microbiology Laboratory, State University of Vale do Acaraú and Microsporum canis was obtained from the skin of symptomatic dogs with dermatophytosis. M. canis strain was recovered and identified based on the macromorphology and micromorphology of the colonies (De Hoog et al., 2008). Suspension aliquots were taken and prepared in potato dextrose agar (Difco, Detroit, MI, USA), plus $0.1 \%$ chloramphenicol and then incubated at $28^{\circ} \mathrm{C}$ for $5-10$ days. The suspensions were diluted to 1:500, with RPMI 1640 medium without sodium bicarbonate but with L-glutamine, and then buffered to $\mathrm{pH} 7.0$ with $0.165 \mathrm{M}$ MOPS. Lachnophyllum ester was prepared in $100 \%$ mineral oil, while ketoconazole was prepared in DMSO. For evaluating the antifungal effect ketoconazole was used as the standard drug. Lachnophyllum ester was tested in concentrations ranging from 0.002 to 2.5 $\mathrm{mg} / \mathrm{mL}$, while ketoconazole was tested in concentrations ranging from 16 $\mu \mathrm{g} / \mathrm{mL}$ to $0.125 \mu \mathrm{g} / \mathrm{mL}$. The antifungal effect was analyzed visually after 5 days of incubated at $37{ }^{\circ} \mathrm{C}$. The antifungal potential was obtained from the minimum inhibitory concentration (MIC) and the minimum fungicidal concentration (MFC) was determined by subculturing $100 \mu \mathrm{L}$ of solution from wells without turbidity on potato dextrose agar at $28^{\circ} \mathrm{C}$, and MFC values were determined as the lowest concentration resulting in no growth of the subculture after 5 days (Fontenelle et al., 2008).

The modulatory assay was performed with all dermatophytes strains by the checkerboard technique (Johnson, 2004; Pyun and Shin, 2006). Interaction of the drugs was determined by calculating the fractional inhibitory concentration index (FICI), where fractional inhibitory concentration (FIC) was defined with the MIC values of each drug in the combination divided by the MIC of the drug alone. The turbidity of the dermatophytes suspensions was adjusted to standard 0.5 on the McFarland scale (105 CFU/mL). Briefly, lachnophyllum ester and ketoconazole were used at concentrations of their respective MIC values, and $50 \mu \mathrm{L}$ of RPMI 1640 medium was added to the wells of 96well microdilution plates. Then $50 \mu \mathrm{L}$ of each dilution of the natural product was added in vertical orientation, with the concentrations ranging from $5 \mathrm{mg} / \mathrm{mL}$ to $0.03 \mathrm{mg} / \mathrm{mL}$. In the horizontal orientation, $50 \mu \mathrm{L}$ of ketoconazole (standard antifungal) was added to all wells in concentrations ranging from 16 $\mu \mathrm{g} / \mathrm{mL}$ to $0.125 \mu \mathrm{g} / \mathrm{mL}$. $100 \mu \mathrm{L}$ from the suspension of dermatophytes strains $(5.0$ x $104 \mathrm{CFU}$ mL-1) and incubated at $37^{\circ} \mathrm{C}$ for 5 days. Checkerboard microdilution test was determined in triplicate. The 
FICI was interpreted as showing a synergistic effect at values $\leq 0.5$, while the indifferent effect at values $>0.5$ or $\leq$ 4.0 , and an antagonistic effect at values $>4.0$ (Odds, 2003; Johnson, 2004).

This assay was conducted as described by Lopes-Lutz et al. (2008) and Andrade et al. (2012). Briefly, a stock solution of emulsion was prepared with $\beta$-carotene $(1 \mathrm{mg})$ dissolved in chloroform $(5 \mathrm{~mL}$, $0.3 \mathrm{mg} / \mathrm{mL})$, linoleic acid $(20 \mu \mathrm{L})$ and Tween $40(200 \mu \mathrm{L})$. Chloroform was completely evaporated in rotary evaporated. After that, $100 \mathrm{~mL}$ of oxygenated distilled water was added and emulsified for $1 \mathrm{~min}$ in a sonicator to form the emulsion, then was adjusted in the spectrophotometer at $470 \mathrm{~nm}$, until an absorbance between $0.6 \mathrm{~nm}$ and 0.7 $\mathrm{nm}$ was obtained. Aliquots of $100 \mu \mathrm{l}$ of lachnophyllum ester were dissolved in methanol, at concentrations of 500 $\mu \mathrm{g} / \mathrm{mL}$ to $25 \mu \mathrm{g} / \mathrm{mL}$, and then $\beta$ carotene/linoleic acid emulsion $(5 \mathrm{~mL})$ was added. The sample absorbance was measured after $2 \mathrm{~min}$, then the samples were subjected to oxidation by placement in an oven for $120 \mathrm{~min}$ at 50 ${ }^{\circ} \mathrm{C}$, and a second reading was performed. The same procedure was repeated with ascorbic acid and the synthetic antioxidant butylated hydroxytoluene (BHT) as positive controls, and a blank. Antioxidative capacity of the lachnophyllum ester was compared with those of ascorbic acid, BHT and the blank. Each antioxidant test was determined in triplicate and the average and standard deviation were calculated.

Data analysis was carried out by oneway ANOVA with the Tukey test followed by multiple comparison testing at $\mathrm{p}<0.05$. IC50 values were acquired with GraphPad Prism software 7.0 (GraphPad Software, San Diego, CA).

\section{RESULTS AND DISCUSSION}

Lachnophyllum ester, an important compound found in the Asteraceae family, also used as chemotaxonomic marker, is a poly-unsaturated aliphatic methyl ester that was first isolated from the plant Lachnophyllum gossypinum Bunge in 1935 (Bruun et al., 1950). It was previously characterized, identified and isolated in $B$. trinervis by Albuquerque et al. (2004).

The compound corresponds to methyl (Z)-dec-2-en-4,6-diynoate

(lachnophyllum ester), a matricaria ester-type polyacetylenes (Figure 1). These esters are important compounds with conjugated triple and double bonds and are present in the essential oils of several Asteraceae species, generally useful in systematic studies (Shi Shun and Tykwinski, 2006). The number of carbon atoms in the ester chain is often characteristic of tribes or genera (Nazaruk and Kalemba, 2009).

Figure 1. Chemical structure of lachnophyllum ester (methyl (Z)-dec-2en-4,6-diynoate).

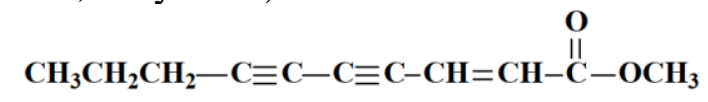

The acetylene esters are interesting compounds due to their biotechnology potential. Lachnophyllum and matricaria esters and lactones possess pharmacological and antimicrobial properties, such as antifungal (Vidari et al., 2006; Rahalison et al., 1995), antimycobacterial (Lu et al., 1998), nematicidal (Kimura et al., 1981) and allelopathic (Tzakou et al., 2004). Acetylene esters exhibit cytotoxic activity, and are potent human tumor cell 
inhibitors, such as MDA-MD-231, MCF-7 (Satyal et al., 2015).

B. trinervis essential oil was submitted to silica gel column chromatography, and the lachnophyllum ester was isolated and characterized by gas chromatography / mass spectrometry, with the data analyzed and corroborated by literature values (Albuquerque et al., 2004).

The antioxidant effect was ascertained by the $\beta$-carotene/linoleic acid system assay and the results for lachnophyllum ester showed inhibition of linoleic acid oxidation and capacity of $\beta$-carotene to protect against rapid discoloration and oxidation in the emulsion. Lachnophyllum ester showed $71.43 \% \pm$ $0.01 \%$ inhibition rate. BHT (butylated hydroxyl-toluene) and ascorbic acid were used as standards, with antioxidant effects of $96.43 \% \pm 0.23 \%$ and $94.5 \% \pm$ $2.14 \%$, respectively.

This method is very useful to analyze lipophilic substances such as essential oils, fixed oils and their constituents, based on the coupled oxidation of $\beta$ carotene and linoleic acid, which generates free radicals that cause rapid discoloration of $\beta$-carotene in the absence of an antioxidant (Sarikurkcu et al., 2009).

The antioxidant capacity using the $\beta$ carotene/linoleic acid system measures the inhibition of formation of the conjugated diene hydroperoxide arising from the linoleic acid oxidation, which can simulate the oxidation of the cell membrane lipid components (Silva and Jorge, 2019.

The antifungal activity against dermatophytic fungi is shown in Table 1, where lachnophyllum ester had antimicrobial action against all strains, with the lowest inhibitory concentration being observed for T. rubrum LABMIC 0101 strain (MIC of $0.625 \mathrm{mg} / \mathrm{mL}$ ). For the fungicidal activity, the minimum fungicidal concentration (MFC) values ranged from 1.25 and $5.0 \mathrm{mg} / \mathrm{mL}$ for $T$. rubrum and $M$. canis strains. The long hydrocarbon aliphatic chain confers low polarity to ester, which facilitates the permeability in the phospholipid bilayer of the fungal cells and may explain the antimicrobial effect found.

Table 1. Minimum inhibitory concentration of lachnophyllum ester from essential oils of Baccharis trinervis against dermatophyte strains.

\begin{tabular}{llll}
\hline Strains & \multicolumn{2}{l}{ Lachnophyllum ester } & $\begin{array}{l}\text { Drug } \\
(\boldsymbol{\mu g} / \mathbf{m L})\end{array}$ \\
\hline & $\begin{array}{l}\text { MIC } \\
(\mathrm{mg} / \mathrm{mL})\end{array}$ & $\begin{array}{l}\text { MFC } \\
(\mathrm{mg} / \mathrm{mL})\end{array}$ & ketoconazole \\
& $0.625^{\mathrm{a}}$ & $1.25^{\mathrm{c}}$ & $1.0^{\mathrm{b}}$ \\
T. rubrum LABMIC 0101 & $5.0^{\mathrm{c}}$ & $1.0^{\mathrm{a}}$ \\
T. rubrum LABMIC 0102 & $2.5^{\mathrm{b}}$ & $5.0^{\mathrm{c}}$ & $1.0^{\mathrm{a}}$ \\
M. canis LABMIC KIM & $2.5^{\mathrm{b}}$ & canic & \\
\hline
\end{tabular}

Equal lowercase letters in the columns indicate significant similarities $(\mathrm{p}<0.0001$, ANOVA followed by Tukey test). Ketoconazole was used as positive control.

The results of the combined effects of lachnophyllum ester and ketoconazole are reported in Table 2. These results indicate a synergistic interaction between lachnophyllum ester and ketoconazole against $T$. rubrum strains (FICI in the 0.3-0.5 range), but the interaction between the antifungal and 
M. canis indicated an indifferent effect

(FICI in the 0.6).

Table 2. MIC of the ketoconazole in the presence and absence of lachnophyllum ester from essential oils from Baccharis trinervis against dermatophyte strains.

\begin{tabular}{llll}
\hline Plant essential oil/Drug & \multicolumn{4}{l}{ T. rubrum LABMIC 0101 } \\
\hline & MIC $(\mu \mathrm{g} / \mathrm{mL})$ & MIC $(\mu \mathrm{g} / \mathrm{mL})$ & FICI \\
& Alone & Combined & \\
Lachnophyllum ester & 625 & 39 & 0.31 \\
Ketoconazole & 2.0 & 0,5 & \\
& T. rubrum LABMIC 0102 & \\
& MIC $(\mu \mathrm{g} / \mathrm{mL})$ & MIC $(\mu \mathrm{g} / \mathrm{mL})$ & FICI \\
& Alone & Combined & \\
Lachnophyllum ester & 2500 & 39 & 0.51 \\
Ketoconazole & 1 & 0,5 & \\
& M. canis LABMIC KIM & \\
& MIC $(\mu \mathrm{g} / \mathrm{mL})$ & MIC $(\mu \mathrm{g} / \mathrm{mL})$ & FICI \\
Lachnophyllum ester & Alone & Combined & \\
Ketoconazole & 2500 & 312 & 0.62 \\
\hline a FICI: fractional inhibitory concentration index & 0,5 & \\
\hline
\end{tabular}

Dermatophytes are fungi with keratin affinity that have great importance in human and animal health, being responsible for causing skin infections, such as tineas. On the other hand, $T$. rubrum, an anthropophilic dermatophyte, is found in $60 \%$ of these onychomycosis infections, such as tinea unguium (Flores et al., 2016). This study is important, especially in relation to the checkerboard assay, because conventional therapies often have severe adverse effects and are ineffective due to resistance to standard antifungal drugs (Gupta and Simpson, 2015).

The mechanisms by which lachnophyllum ester inhibits microbial growth may be related to its low polarity. This constituent can act on the phospholipid bilayer, causing it to become more permeable to antifungal agents, affecting the cellular energy production and the mitochondrial respiratory chain. Thus, a synergistic effect between ketoconazole a lachnophyllum ester may modulate the antimicrobial response at sub-inhibitory concentrations (Tintino et al., 2014). The synergistic interaction between the lachnophyllum ester and ketoconazole may be useful in future studies involving pharmaceutical formulations and the development of drugs for the treatment of fungal infections that use less concentration of azole derivatives.

The antioxidant and antimicrobial properties of natural products are of great interest in the development of bioproducts and additives in the drug and food industry. In addition, natural antioxidants are potent free radical stabilizers, combating oxidative stress and strengthening the immune system, a feature useful for antimicrobials. This is 
the first report of the antioxidant, antidermatophytic and modulatory activities of lachnophyllum ester.

\section{CONCLUSION}

Baccharis trinervis (Lam.) Pers. is a medicinal plant native to South America from which lachnophyllum ester was isolated by silica gel column chromatography and characterized by GC/MS. A previous study already characterized this compound from plants of the Asteraceae family (Sobrinho et al., 2016), but this is the first report involving its antioxidant and antidermatophytic properties.

Lachnophyllum ester was able to inhibit oxidation in the $\beta$-carotene/linoleic acid system with considerable antioxidant action. This compound showed in vitro antifungal potential against $T$. rubrum and $M$. canis strains, with fungistatic and fungicidal activities, in addition to modulatory activity. The interaction was synergistic, reducing the MIC values of the antifungal drug and modulating its antifungal action against dermatophyte strains.

\section{ACKNOWLEDGEMENTS}

We are grateful to the Postgraduate Program in Biotechnology of State University of Ceará and the university's Laboratory for Natural Products Chemistry, as well as to the Microbiology Laboratory of State University of Vale do Acaraú. Financing was provided by the Office to Coordinate Improvement of University Personnel (CAPES) of the Ministry of Education.

\section{REFERENCES}

ADAMS, R. P. Identification of Essential Oil Components by Gas Chromatography/Mass Spectrometry. Allured Publishing Corporation, Illinois. 2017. 804 p.

ALBUQUERQUE, M. R. J. R.; SOUZA, E. B.; LINS, M. U. D. S.; NOGUEIRA, N. A. P.; LEMOS, T. L. G.; SILVEIRA, E. R.; PESSOA, O. D. L. Composition and antimicrobial activity of the essential oil from aerial parts of Baccharis trinervis (Lam.) Pers. Arkivoc, v. 6, p. 59-65, 2004.

ANDRADE, M. A.; CARDOSO, M. D. G.; BATISTA, L. R.; MALLET, A. C. T.; MACHADO, S. M. F. Óleos essenciais de Cymbopogon nardus, Cinnamomum zeylanicum e Zingiber officinale: composição, atividades antioxidante e antibacteriana. Revista Ciência Agronômica, v. 43, n. 2, p. 399408, 2012.

BERLIN, E. A.; BERLIN, B. Medical ethnobiology of the highland Maya of Chiapas, Mexico: the gastrointestinal diseases. Princeton University Press. 2015

BOHLMANN, F. Naturally-occurring acetylenes. Chemistry and biology of naturally-occurring acetylenes and related compounds. (NOARC) 1-19, 1988.

BOUCHARA, J. P.; MIGNON, B.; CHATURVEDI, V. Dermatophytes and dermatophytoses: a thematic overview of state of the art, and the directions for future research and developments. Mycopathologia, v. 182, p. 1-4, 2017. 
BRUUN, T.; HAUG, C. M.; SÖRENSEN, N. A. The Synthesis of trans-Lachnophyllum Ester. Acta Chemica Scandinavica, v. 4, n. 6, p. 850-855, 1950.

\section{CLINICAL AND LABORATORY} STANDARDS INSTITUTE. Reference Method for Broth Dilution Antifungal Susceptibility Testing of Filamentous Fungi (Approved Standard. Document M38. CLSI). Second ed.vol. M38-A2. Clinical and Laboratory Standards Institute, Wayne, PA, 2008. $13 \mathrm{p}$.

DE HOOG, G. S.; GUARRO, J.; GENÉ, J.; FIGUERAS, M. J. Atlas of Clinical Fungi, 4th edn. Utrecht, The Netherlands: Centralalbureau voor Schimmelcultures/Universitat Rovira I Virgili Reus, 2008. 1160 p.

FLORES, F. C.; BECK, R. C.; SILVA, C. D. B. Essential oils for treatment for onychomycosis: a mini-review. Mycopathologia, v. 181, n. 1-2, p. 9-15, 2016.

FONTENELLE, R. O. S.; MORAIS, S. M.; BRITO, E. H. S.; BRILHANTE, R. S. N.; CORDEIRO, R. A.; NASCIMENTO, N. R. F.; KERNTOPF, M. R.; SIDRIM, J. J. C.; ROCHA, M. F. G. Antifungal activity of essential oils of Croton species from the Brazilian Caatinga biome. Journal of Applied Microbiology, v. 104, n. 5, p. 13831390, 2008.

GUPTA, A. K.; SIMPSON, F. C. New pharmacotherapy for the treatment of onychomycosis: an update. Expert opinion on pharmacotherapy, v. 16, n. 2, p. 227-236, 2015.
HARVEY, A. L.; EDRADA-EBEL, R.; QUINN, R. J. The re-emergence of natural products for drug discovery in the genomics era. Nature reviews drug discovery, v. 14, n. 2, p. 111-129, 2015.

JOHNSON, M. D.; MACDOUGALL, C.; OSTROSKY-ZEICHNER, L.; PERFECT, J. R.; REX, J. H. Combination antifungal therapy. Antimicrobial Agents and Chemotherapy, v. 48, n. 3, p. 693-715, 2004.

JUMMES, B.; SGANZERLA, W. G.; ROSA, C. G.; NORONHA, C. M.; NUNES, M. R.; BERTOLDI, F. C.; BARRETO, P. L. M. Antioxidant and antimicrobial poly- $\varepsilon$-caprolactone nanoparticles loaded with Cymbopogon martinii essential oil. Biocatalysis and Agricultural Biotechnology, v. 23, p. 101499, 2020.

KIMURA, Y.; MORI, M.; SUZUKI, A.; KOBAYASHI, A. Isolation and identification of two nematicidal substances from roots of Erigeron philadelphicus L. and nematicidal activities of their related compounds. Agricultural and Biological Chemistry, v. 45 , n. 12 , p. $2915-2917$, 1981.

KUROYANAGI, M.; UCHIDA, K.; UENO, A.; SATAKE, M.; SHIMOMURA, K. Neo-clerodane type diterpenes from Baccharis trinervis. Phytochemistry, v. 34, n. 5, p. 13771384, 1993.

LOPES-LUTZ, D.; ALVIANO, D. S.; ALVIANO, C. S.; KOLODZIEJCZYK, P. P. Screening of chemical composition, 
antimicrobial and antioxidant activities of Artemisia essential oils. Phytochemistry, v. 69 , n. 8 , p. $1732-$ 1738, 2008.

LU, T.; CANTRELL, C. L.; ROBBS, S. L.; FRANZBLAU, S. G.; FISCHER, N. H. Antimycobacteral matricaria esters and lactones from Asteraceae species. Planta Medica, v. 64, n. 07, p. 665-667, 1998.

NAZARUK, J.; KALEMBA, D. Chemical Composition of the Essential Oils from the Roots of Erigeron acris L. and Erigeron annuus (L.) Pers. Molecules, v. 14, n. 7, p. 2458-2465, 2009.

NAZZARO, F.; FRATIANNI, F.; COPPOLA, R.; FEO, V. D. Essential oils and antifungal activity Pharmaceuticals, v. 10 , n. 4, p. 86 , 2017.

ODDS, F. C. Synergy, antagonism, and what the chequerboard puts between them. Journal of Antimicrobial Chemotherapy, v. 52, n. 1, p. 1-1, 2003.

PYUN, M. S.; SHIN, S. Antifungal effects of the volatile oils from Allium plants against Trichophyton species and synergism of the oils with ketoconazole. Phytomedicine, v. 13, n. 6, p. 394-400, 2006.

RAHALISON, L.; BENATHAN, M.; MONOD, M.; FRENK, E.; GUPTA, M. P.; SOLIS, P. N.; FUZZATI, N.; HOSTETTMANN, K. Antifungal principles of Baccharis pedunculata. Planta Medica, v. 61, n. 04, p. 360-362, 1995.
RAMÍREZ-CÁRDENAS，A.; ISAZAMEJÍA, G.; PÉREZ-CÁRDENAS, J. E. Especies vegetales investigadas por sus propiedades antimicrobianas, inmunomoduladoras e hipoglicemientes en el Departamento de Caldas (Colombia, Sudamérica). Revista Biosalud Manizales, v. 12, n. 1, p. 5982, 2013.

SARIKURKCU, C.; ARISOY, K.; TEPE, B.; CAKIR, A.; ABALI, G.; METE, E. Studies on the antioxidant activity of essential oil and different solvent extracts of Vitex agnus castus L. fruits from Turkey. Food and Chemical Toxicology, v. 47, n. 10, p. 2479-2483, 2009.

SATYAL， P.; CHHETRI, B. K.; DOSOKY, N. S.; SHRESTHA, S.; POUDEL, A.; SETZER, W. N. Chemical Composition of Blumea lacera Essential Oil from Nepal. Biological Activities of the Essential Oil and (Z)Lachnophyllum Ester. Natural Product Communications, v. 10 , n. 10 , p. 17491750, 2015.

SHARP, H.; BARTHOLOMEW, B.; BRIGHT, C.; LATIF, Z.; SARKER, S. D.; NASH, R. J. 6-Oxygenated flavones from Baccharis trinervis (Asteraceae). Biochemical Systematics and Ecology, v. 29, n. 1, p. 105-107, 2001.

SHI-SHUN, A. L.; TYKWINSKI, R. R. Synthesis of naturally occurring polyynes. Angewandte Chemie International Edition, v. 45, n. 7, p. 1034-1057, 2006.

SILVA, A. C.; JORGE, N. Bioactive properties and antioxidant capacity of oils extracted from citrus fruit seeds. 
Acta Alimentaria, v. 48, n. 2, p. 196203, 2019.

SOBRINHO, A. C. N.; SOUZA, E. B.; ROCHA, M. F. G.; ALBUQUERQUE, M. R. J. R.; BANDEIRA, P. N.; SANTOS, H. S.; CAVALCANTE, C. S. P.; OLIVEIRA, S. S.; ARAGÃO, P. R.; MORAIS, S. M.; FONTENELLE, R. O. S. Chemical composition, antioxidant, antifungal and hemolytic activities of essential oil from Baccharis trinervis (Lam.) Pers. (Asteraceae). Industrial Crops and Products, v. 84, p. 108-115, 2016.

TABASSUM, N.; VIDYASAGAR, G. $M$. Antifungal investigations on plant essential oils. A review. International Journal of Pharmacy and Pharmaceutical Sciences, v. 5, p. 1928, 2013.

TINTINO, S. R.; SOUZA, C. E.; GUEDES, G. M.; COSTA, J. I.; DUARTE, F. M.; CHAVES, M. C. O.; SILVA, V. A.; PESSOA, H. L.; LIMA, M. A.; GARCIA, C. A.; COUTINHO, H. D. Modulatory antimicrobial activity of Piper arboreum extracts. Acta Botanica Croatica, v. 73, n. 1, p. 303-311, 2014.

TZAKOU, O.; GANI, A.; ECONOMOU, G.; YANNITSAROS, A. Chemical composition and allelopathic activity of oil and volatile fractions of Conyza albida Willd. Ex Sprengel from Greece. Journal of Essential Oil Research, v. 16, n. 5, p. 425-428, 2004.

VIDARI, G.; ABDO, S.; GILARDONI, G.; CIAPESSONI, A.; GUSMEROLI, M.; ZANONI, G. Fungitoxic metabolites from Erigeron apiculatus. Fitoterapia, v. 77, n. 4, p. 318-320, 2006. 